\title{
Can fatty acids and oxytetracycline protect artificially raised larvae from developing European foulbrood?*
}

\author{
Thomas GIERSCH, Idris BARCHIA, Michael HORNITZKY \\ Elizabeth Macarthur Agricultural Institute, New South Wales Department of Primary Industries, \\ Private Mail Bag, 8, Camden, New South Wales, 2570, Australia
}

Received 18 March 2009 - Revised 16 June 2009 - Accepted 31 July 2009

\begin{abstract}
A quantitative assay for the transmission of European foulbrood (EFB) in artificially raised larvae was developed. This assay was used to determine the concentration of oxytetracycline (OTC) required to prevent larvae from developing EFB and whether 8 fatty acids (undecanoic, lauric [dodecanoic], myristic, myristoleic, ricinoleic, ricinelaidic, homo-y-linolenic and 13,16,19-docosatrienoic acids) which had previously been demonstrated to inhibit the growth of Melissococcus plutonius cultures, could protect larvae from developing EFB. The larval assay involved grafting individual larva (less than 24 hours old) into a single well in a micro-titre plate. Each larva was fed $10 \mu \mathrm{L}$ of basic larval diet (BLD) containing 500000 M. plutonius organisms. After 3 days the larvae were also fed 60000 Paenibacillus alvei spores (a common secondary invader associated with EFB) in $10 \mu \mathrm{L}$ BLD. The combination of these two organisms was required to reliably produce symptoms typical of that seen in field cases of EFB. Most larvae infected using this protocol died from EFB. To determine the efficacy of OTC, EFB infected larvae were fed 0, 1, $2.5,510$ or $20 \mu \mathrm{g} / \mathrm{mL}$ of OTC. Treatment with $1 \mu \mathrm{g} / \mathrm{mL}$ lowered the mortality rate from $93.75 \%$ to $69.5 \%$. Treatments with $2.5 \mu \mathrm{g} / \mathrm{mL}$ to $10 \mu \mathrm{g} / \mathrm{mL}$ reduced the mortality rate further whereas treatment with $20 \mu \mathrm{g} / \mathrm{mL}$ reduced the rate to the same as the negative control. Larvae fed 20 or $200 \mu \mathrm{g} / \mathrm{mL}$ of each of the eight fatty acids were not protected from developing EFB.
\end{abstract}

\section{Melissococcus plutonius / European foulbrood treatment / oxytetracycline / Paenibacillus alvei / fatty acids}

\section{INTRODUCTION}

European foulbrood (EFB) is a relatively poorly understood bacterial disease when compared with American foulbrood (AFB), the other major bacterial disease of honey bees. Researchers have not commonly attempted to transmit EFB to honey bee colonies due to the unreliability in producing disease. This is probably because the transmission of EFB is hampered by uncontrollable environmental conditions and the ejection of infected larvae by adult bees from inoculated colonies (Bailey, 1960). Inoculated colonies often re-

Corresponding author: M. Hornitzky, michael.hornitzky@dpi.nsw.gov.au

* Manuscript editor: Peter Rosenkranz quire artificial manipulation, such as the removal of foraging adult bees, to increase their susceptibility to EFB (Bailey, 1960).

Techniques for transmitting $\mathrm{EFB}$ to colonies have been developed to instigate and confirm the cause of the disease (Tarr, 1936; Bailey, 1963; Bailey and Lochner, 1968). However, only one reliable method for infecting colonies or laboratory raised larvae with $M$. plutonius has been published (McKee et al., 2004). This method was successful in transmitting disease by feeding $M$. plutonius from EFB diseased material using EFB diseased larval extracts. However, the dose required to produce disease could only be estimated as the amount of infective material consumed by the larvae could not be accurately determined. EFB could not be 
transmitted by feeding $M$. plutonius cultures grown on an artificial medium, using the McKee et al. (2004) assay.

Unlike AFB, in which only the causative agent is involved in the disease process, EFB is associated with a number of secondary invaders (Bailey, 1960). One of the most common secondary invaders is Paenibacillus alvei. The role of $P$. alvei in the disease process is unknown.

Oxytetracycline (OTC) is the antibiotic of choice for the treatment of EFB. However, there are still unanswered questions about EFB and its treatment with OTC that need further study. Although OTC has been used to treat EFB for decades, the concentration of OTC in honey bee larvae required to protect them from developing EFB is still unknown. This information would provide an indication as to how much OTC is required to protect honey bee larvae from EFB and how much OTC is required for colony treatment.

Alternative methods for the control of EFB are needed if problems with residues are to be eliminated. In 1992 Shimanuki et al. (1992) demonstrated that chalkbrood mummies contained an antimicrobial substance which in laboratory tests inhibited the growth of $P$. larvae and M. plutonius. Feldlaufer et al. (1993) subsequently identified this substance to be the fatty acid linoleic acid. They also demonstrated that linoleic acid was active against $P$. larvae but did not test its effect on M. plutonius. Hornitzky (2003) tested 28 fatty acids for their activity against $P$. larvae and M. plutonius cultures. Fifteen of the fatty acids showed antibacterial activity against $P$. larvae and eight fatty acids showed activity against $M$. plutonius. As control agents fatty acids would be safe and environmentallysound (Feldlaufer et al., 1993). Not only are these agents non-toxic to man but are actual foods and in the case of unsaturated fatty acids are essential for growth, development and health (Kabara, 1978).

The aims of this study were to develop a quantitative assay for the transmission of EFB in artificially raised larvae and to determine whether $P$. alvei has a role in the EFB disease process. This study was also carried out to determine the concentration of OTC required to prevent the development of EFB in honey bee larvae and to determine whether any of the eight fatty acids previously shown to inhibit the growth of $M$. plutonius could prevent honey bee larvae from developing EFB (Hornitzky, 2003).

\section{MATERIALS AND METHODS}

\subsection{Collection of larvae}

Worker honey bee larvae (Apis mellifera) were obtained from 3 colonies of Italian strain bees maintained at the Elizabeth Macarthur Agricultural Institute, Menangle, NSW. Individual larvae $<24$ hour old were grafted into single wells of sterile 96-well cell culture plates (Greiner cellstar U-shape) using a size 00 paintbrush.

\subsection{Preparation of $M$. plutonius and $P$. alvei inocula}

\subsubsection{M. plutonius}

One of two duplicate smears prepared from individual larvae exhibiting clinical signs of EFB was examined microscopically after carbol-fuchsin staining for bacterial populations (Hornitzky and Wilson, 1989). From larval smears that were only infected with $M$. plutonius, the second smear was reconstituted with water and streaked on EBN culture plates (Hornitzky and Smith, 1998). The plates were incubated at $37^{\circ} \mathrm{C}$ under anaerobic conditions for 5 days. M. plutonius was subcultured from single colonies on EBN plates and incubated as described above.

The inoculum was prepared by suspending the bacterial growth in $250 \mu \mathrm{L}$ sterile distilled water per plate. The suspension was washed by centrifugation for $20 \mathrm{~s}$ at $18000 \times g$ and resuspending the pellet in $1 / 5$ th of the washing volume. The concentration of bacteria was determined microscopically with a Neubauer haemocytometer. As most M. plutonius harvested from culture plates appear as short chains, each chain was counted as a single infective unit. The $M$. plutonius cell suspension was frozen in $50 \mu \mathrm{L}$ aliquots and stored at $-80^{\circ} \mathrm{C}$. 
Table I. Feeding and monitoring schedule for all larval raising experiments.

\begin{tabular}{cccccccccccc}
\hline Hpg & 0 & 67 & 73 & 90 & 97 & 114 & 121 & 138 & 145 & 162 & 169 \\
\hline & $*$ & $*$ & $*$ & $*$ & $*$ & $*$ & $*$ & $*$ & $*$ & $*$ & $*$ \\
& + & + & + & + & + & + & + & + & + & + & \\
& $\Uparrow$ & $\uparrow$ & & & & & & $\wedge 1$ & & & $\wedge 2$ \\
\hline
\end{tabular}

hpg $=$ hours post grafting

* = monitor larvae and assess viability

$+=$ feed larvae

$\wedge^{1}=$ prepare smears from dead larvae

$\wedge^{2}=$ prepare smears from all remaining larvae

$\Uparrow=$ inoculation (feeding) with M. plutonius

$\uparrow=$ inoculation (feeding) with $P$. alvei

\subsubsection{P. alvei}

Smears from larvae with clinical signs of EFB were examined microscopically to confirm the presence of $P$. alvei. Smears containing $P$. alvei spores were resuspended in a drop of sterile distilled water (SDW) and streaked onto 7\% sheep blood plates. After incubation for 3 days at $37{ }^{\circ} \mathrm{C}$ under aerobic conditions, single colonies were subcultured. Subcultures were expanded on blood plates and incubated for 6 days so that $P$. alvei spores were prevalent. The spores were scraped off the plates with a cell scraper, suspended in SDW ( $3 \mathrm{~mL} /$ plate) and washed 4 times in SDW by repeated spinning $(5 \mathrm{~min}$ at $6000 \times \mathrm{g})$ and resuspending of the pellet. The spores were finally resuspended in $0.5 \mathrm{~mL} \mathrm{SDW} /$ plate and counted in a Neubauer haemocytometer. $P$. alvei spores were frozen in $50 \mu \mathrm{L}$ aliquots and stored at $-80^{\circ} \mathrm{C}$.

\subsection{Larval assay}

Larvae were fed a modified basic larval diet (BLD) (Peng et al., 1992). BLD was prepared by mixing $4.2 \mathrm{~g}$ freeze dried royal jelly into a solution of $0.6 \mathrm{~g}$ D-glucose (Ajax, 1364), $0.6 \mathrm{~g}$ D-(-)-fructose (Sigma F-3510) and 0.2 g yeast extract (Bacto) dissolved in $14.4 \mathrm{~mL}$ sterile distilled water. The sugar/yeast solution was sterile filtered and stored at $4{ }^{\circ} \mathrm{C}$. Fresh royal jelly was obtained from Natural Life (Australia), freeze dried in $20 \mathrm{~g}$ aliquots and stored at $-20{ }^{\circ} \mathrm{C}$ until required for the preparation of BLD.

The required amount of complete BLD was prepared for each experiment and stored at $4{ }^{\circ} \mathrm{C}$ for no longer than 5 days. Before feeding bee larvae the
BLD was pre-heated to $35^{\circ} \mathrm{C}$. To ensure homogeneous distribution of inocula containing $M$. plutonius and $P$. alvei the bacteria or spores were suspended in the liquid component of BLD before adding royal jelly.

Each well into which a larva was grafted contained $10 \mu \mathrm{L}$ pre-warmed BLD or BLD containing inoculum and treatment as shown in Table I. Larvae were reared in an incubator (Labec, Australia) at $35{ }^{\circ} \mathrm{C}$ with a tray of SDW to maintain high humidity. From 67 hours post grafting the larvae were examined for mortality and fed twice a day. Six to $10 \mu \mathrm{L}$ of the diet were deposited near the head of the larvae using a direct displacement multistepper pipette. Larvae that died during an experiment were smeared on slides and the infection rate $(M$. plutonius and $P$. alvei) was determined microscopically after carbol fuchsin staining. The rearing was terminated 169 hours post grafting and the number of live larvae and the infection status of all remaining larvae was determined.

\subsection{Bacterial inocula and OTC treatment}

To determine the optimum $M$. plutonius inoculum for the assay larvae were fed with increasing concentration of M. plutonius from $10^{5}$ to $10^{9}$ infective units/mL BLD $\left(=10^{3}-10^{7}\right.$ infective units/larva $)$ at grafting. To determine the role of $P$. alvei larvae were also fed with $M$. plutonius from $10^{5}$ to $10^{9}$ infective units $/ \mathrm{mL} \mathrm{BLD}\left(=10^{3}-10^{7} /\right.$ larvae $)$ at grafting and subsequently fed with $P$. alvei with a dose of $6 \times 10^{6}$ spores $/ \mathrm{mL}\left(=6 \times 10^{4} /\right.$ larvae $)$ after 67 hours.

Test larvae were fed 500000 M. plutonius organisms in $10 \mu \mathrm{L}$ in the BLD which was placed in 
Table II. OTC treatment regime.

\begin{tabular}{lccc}
\hline Group & \multicolumn{3}{c}{ Treatment + BLD } \\
\hline & M. plutonius & P. alvei & OTC \\
\hline 1. Uninfected control & 0 & 0 & 0 \\
2. Infected control & 500000 & 60000 & 0 \\
3. Infected + OTC & 500000 & 60000 & $1 \mu \mathrm{g} / \mathrm{mL}$ \\
4. Infected + OTC & 500000 & 60000 & $2.5 \mu \mathrm{g} / \mathrm{mL}$ \\
5. Infected + OTC & 500000 & 60000 & $5 \mu \mathrm{g} / \mathrm{mL}$ \\
6. Infected + OTC & 500000 & 60000 & $10 \mu \mathrm{g} / \mathrm{mL}$ \\
7. Infected + OTC & 500000 & 60000 & $20 \mu \mathrm{g} / \mathrm{mL}$ \\
\hline
\end{tabular}

the base of the microtitre plate well prior to grafting. These larvae were also fed a single dose of 60000 P. alvei organisms after 67 hours.

For each experiment larvae were grafted into two 96-well plates in 5 or 6 groups of 16 larvae/group/plate. Larvae fed OTC at the specified concentration at each feeding point (Tab. II).

\subsection{Fatty acid testing}

Eight fatty acids (undecanoic, lauric [dodecanoic], myristic, myristoleic, ricinoleic, ricinelaidic, homo-y-linolenic and 13,16,19-docosatrienoic acids) that have shown inhibitory effects against $M$. plutonius were used in this study (Hornitzky, 2003). Stock solutions and dilutions of 100 times the final concentrations were prepared in $\mathrm{EtOH}$ and stored at $-20{ }^{\circ} \mathrm{C}$. One percent of each fatty acid stock solutions was added to BLD to produce the required final concentration of 20 or $200 \mu \mathrm{g} / \mathrm{mL}$.

To determine any toxicity of fatty acids or $1 \%$ ethanol healthy honey bee larvae were fed lauric acid at concentrations of 20,200 and $2000 \mu \mathrm{g} / \mathrm{mL}$ with a final concentration of $1 \%$ ethanol. Four treatment groups of larvae were used for each assay. For each experiment larvae were grafted into two 96-well plates in 4 groups of 24 larvae/group/plate (Tab. III). A duplicate experiment was carried out on a separate occasion for each fatty acid.

\subsection{Statistical analysis}

The objective of this analysis was to compare treatments with untreated EFB infected honey bee larvae (positive control). Data from OTC treatment groups and from fatty acid groups were analysed separately. The larval mortality was observed regularly between 67 to $169 \mathrm{hr}$ after grafting. Data (time when the larvae were found dead) were
Table III. Fatty acid treatment regime.

\begin{tabular}{lccc}
\hline Group & \multicolumn{3}{c}{ Treatment + BLD } \\
\hline & M. plutonius & P. alvei & Fatty acid \\
\hline 1. Uninfected control & 0 & 0 & 0 \\
2. Infected control & 500000 & 60000 & 0 \\
3. Infected + fatty acid & 500000 & 60000 & $20 \mu \mathrm{g} / \mathrm{mL}$ \\
4. Infected + fatty acid & 500000 & 60000 & $200 \mu \mathrm{g} / \mathrm{mL}$ \\
\hline
\end{tabular}

analysed using a parametric survival regression analysis (Kalbfleisch and Prentice, 1980). Time was subtracted by $60 \mathrm{hr}$ to give a better fit to Weibull distribution on the accelerated failure time. The survivor function of larvae from each treatment group was considered as follows:

$$
\mathrm{S}(t)=\exp \left(-\lambda t^{\alpha}\right)
$$

with link function being

$$
\log _{\mathrm{e}}(\lambda)=\text { Treatment effect }
$$

where $\lambda$ is a constant used in Weibull hazard function and $\alpha$ is Weibull distribution shape parameter. All analyses were performed on GenStat version 11 (Payne et al., 2008).

\section{RESULTS}

\subsection{Infection rate and mortality of larvae infected with $M$. plutonius}

As the number of $M$. plutonius organisms fed to larvae increased the percentage of larvae dying from EFB also increased. There was also a trend which linked an increased dose of $M$. plutonius with an increased infection rate. However, it was not as obvious as the mortality trend. The group fed $10^{6}$ organisms/larvae had less infected individuals than the group infected with $10^{5}$ organisms (Fig. 1). To obtain a $100 \%$ infection rate $10^{7} \mathrm{M}$. plutonius organisms were required. None of the negative control larvae developed EFB.

\subsection{Infection rate and mortality of larvae infected with both M. plutonius and $P$. alvei}

There was an increase in the mortality and infection rate of larvae which were fed both $M$. plutonius and $P$. alvei compared to those 


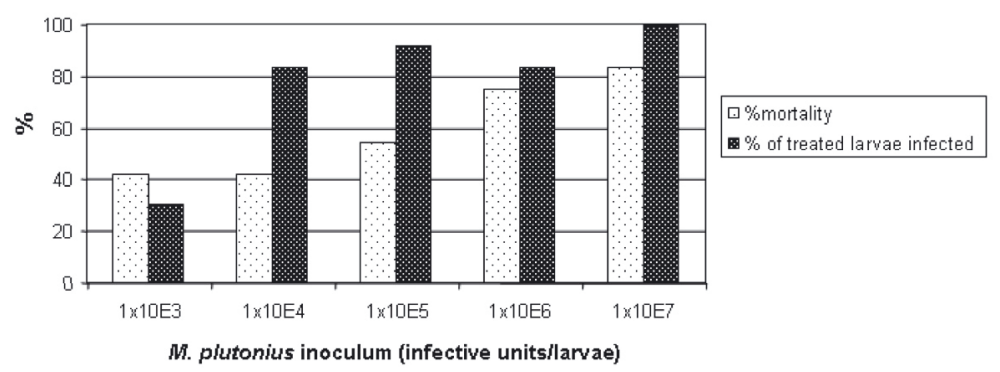

Figure 1. Mortality of honey bee larvae at different infection levels of M. plutonius.

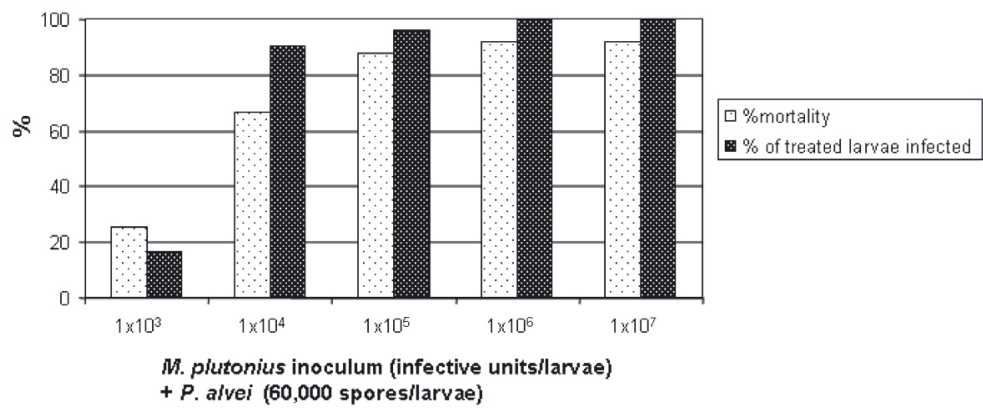

Figure 2. Mortality of honey bee larvae at different infection levels of M. plutonius and secondary infection with $P$. alvei.

Table IV. Survival regression coefficients, standard error and hourly mortality rate $(\lambda)$ from $t=60 \mathrm{hr}$ for treatment groups.

\begin{tabular}{lccccc}
\hline Doses/groups & Parameter & SE & Coefficient & $\lambda$ & Total dead \% \\
\hline Negative control & -8.225 & 0.171 & -8.225 & $0.00027 \mathrm{e}^{\dagger}$ & 31.25 \\
Positive control & 2.093 & 0.195 & -6.132 & $0.00217 \mathrm{a}$ & 93.75 \\
OTC $1 \mu \mathrm{g} / \mathrm{mL}$ & 1.320 & 0.203 & -6.905 & $0.00100 \mathrm{~b}$ & 69.53 \\
OTC $2.5 \mu \mathrm{g} / \mathrm{mL}$ & 0.679 & 0.250 & -7.546 & $0.00053 \mathrm{~cd}$ & 46.87 \\
OTC $5 \mu \mathrm{g} / \mathrm{mL}$ & 0.394 & 0.224 & -7.831 & $0.00040 \mathrm{de}$ & 40.63 \\
OTC $10 \mu \mathrm{g} / \mathrm{mL}$ & 0.906 & 0.241 & -7.319 & $0.00066 \mathrm{c}$ & 54.69 \\
OTC $20 \mu \mathrm{g} / \mathrm{mL}$ & -0.104 & 0.309 & -8.329 & $0.00024 \mathrm{e}$ & 28.12 \\
\hline
\end{tabular}

$\dagger \lambda$ values followed by the same letter are not significantly different at $P=0.05$.

only fed with $M$. plutonius except for the lowest dose of $1 \times 10^{3}$ (Fig. 2). None of the negative control larvae developed EFB.

\subsection{Larval mortalities following OTC treatment of EFB infected larvae}

Feeding larvae with OTC in a concentration range from 1 to $20 \mu \mathrm{g} / \mathrm{mL}$ protected larvae from developing EFB. The coefficient of the survivor regression was highest for the positive control group and this corresponds to the highest mortality rate of the infected larvae. An OTC treatment at $1 \mu \mathrm{g} / \mathrm{mL}$ lowered the mortality rate to $69.2 \%$ compared to the untreated positive mortality of $93.8 \%$. OTC treatments at concentrations of 2.5 to $10 \mu \mathrm{g} / \mathrm{mL}$ reduced the mortality rate further whereas OTC feeding at $20 \mu \mathrm{g} / \mathrm{mL}$ reduced the rate to the same as the negative control (Tab. IV). The predicted survivor function is presented in Figure 3. 
Table V. Survival regression coefficients, standard error and scale parameter $(\lambda)$ from $t=60 \mathrm{hr}$ for fatty acid treatments; Weibull scale $\alpha=1.84 ; \lambda=\exp ($ Coefficient $)$.

\begin{tabular}{lccccccc}
\hline Fatty Acid/doses & Parameter & SE & Coefficient & $\lambda$ & Student $t$ value & Significance & Total dead \% \\
\hline Positive & -7.323 & 0.036 & -7.323 & 0.00066 & $*$ & $*$ & 93.16 \\
LA 20 $\mu \mathrm{g} / \mathrm{mL}$ & 0.403 & 0.150 & -6.920 & 0.00099 & 2.68 & $\mathrm{~ns}$ & 97.92 \\
LA 200 $\mu \mathrm{g} / \mathrm{mL}$ & 0.605 & 0.150 & -6.718 & 0.00121 & 4.04 & $\mathrm{~ns}$ & 97.92 \\
UDA 20 $\mu \mathrm{g} / \mathrm{mL}$ & 0.030 & 0.115 & -7.293 & 0.00068 & 0.26 & $\mathrm{~ns}$ & 95.45 \\
UDA 200 $\mu \mathrm{g} / \mathrm{mL}$ & 0.197 & 0.110 & -7.126 & 0.00080 & 1.8 & $\mathrm{~ns}$ & 96.87 \\
MA 20 $\mu \mathrm{g} / \mathrm{mL}$ & -0.129 & 0.111 & -7.452 & 0.00058 & -1.17 & $\mathrm{~ns}$ & 94.79 \\
MA 200 $\mu \mathrm{g} / \mathrm{mL}$ & -0.002 & 0.110 & -7.325 & 0.00066 & -0.02 & $\mathrm{~ns}$ & 95.83 \\
MLA 20 $\mu \mathrm{g} / \mathrm{mL}$ & 0.110 & 0.111 & -7.213 & 0.00074 & 0.99 & $\mathrm{~ns}$ & 93.75 \\
MLA 200 $\mu \mathrm{g} / \mathrm{mL}$ & -0.018 & 0.111 & -7.341 & 0.00065 & -0.16 & $\mathrm{~ns}$ & 93.75 \\
RLA 20 $\mu \mathrm{g} / \mathrm{mL}$ & 0.006 & 0.112 & -7.317 & 0.00066 & 0.05 & $\mathrm{~ns}$ & 92.71 \\
RLA 200 $\mu \mathrm{g} / \mathrm{mL}$ & -0.116 & 0.114 & -7.439 & 0.00059 & -1.02 & $\mathrm{~ns}$ & 88.54 \\
RLD 20 $\mu \mathrm{g} / \mathrm{mL}$ & -0.151 & 0.112 & -7.474 & 0.00057 & -1.34 & $\mathrm{~ns}$ & 91.67 \\
RLD 200 $\mu \mathrm{g} / \mathrm{mL}$ & -0.152 & 0.112 & -7.475 & 0.00057 & -1.36 & $\mathrm{~ns}$ & 93.68 \\
HLA 20 $\mu \mathrm{g} / \mathrm{mL}$ & -0.026 & 0.110 & -7.349 & 0.00064 & -0.23 & $\mathrm{~ns}$ & 95.83 \\
HLA 200 $\mathrm{gg} / \mathrm{mL}$ & 0.082 & 0.110 & -7.241 & 0.00072 & 0.74 & $\mathrm{~ns}$ & 95.83 \\
DTA 20 $\mu \mathrm{g} / \mathrm{mL}$ & -0.165 & 0.111 & -7.488 & 0.00056 & -1.49 & $\mathrm{~ns}$ & 93.75 \\
DTA 200 $\mu \mathrm{g} / \mathrm{mL}$ & -0.091 & 0.112 & -7.414 & 0.00060 & -0.81 & $\mathrm{~ns}$ & 92.71 \\
Negative & -1.647 & 0.065 & -8.970 & 0.00013 & -25.21 & $<0.001$ & 39.24 \\
\hline
\end{tabular}

$\dagger \mathrm{ns}=$ not significance at $5 \%$ level obtained by one-sided student $t$ test against positive control.

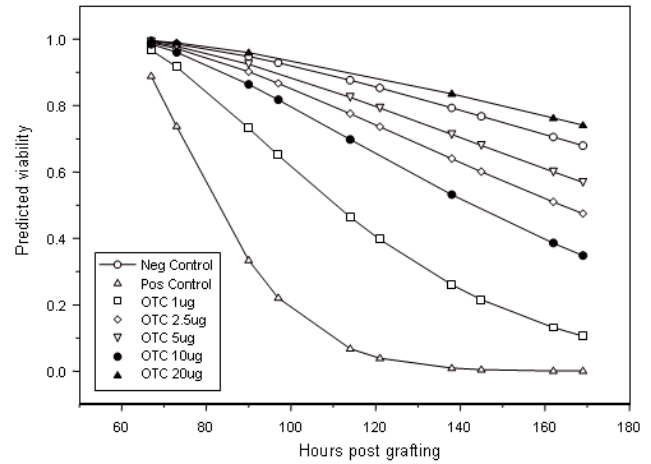

Figure 3. Predicted survivor function of EFB infected larvae treated with different OTC concentrations.

\subsection{Fatty acid testing}

None of the eight fatty acids protected larvae from developing EFB. There was no significant difference between the mortality of the infected control larvae and infected larvae which were also treated with each of the fatty acids. The percentage mortality using the fatty acids ranged from $88.54 \%$ to $97.92 \%$ while the percentage positive control mortal- ity was $93.16 \%$. The negative control mortality was $39.24 \%$ (Tab. V).

Lauric acid was not toxic to honey bee larvae when fed to healthy larvae at concentrations of 20 and $200 \mu \mathrm{g} / \mathrm{mL}$. A concentration of $2000 \mu \mathrm{g} / \mathrm{mL}$ LA caused a $20 \%$ reduction in viability. The ethanol used to dissolve the fatty acids did not affect the viability of larvae at a concentration of $1 \%$.

\subsection{Control larvae}

Although none of the control larvae in this study developed EFB there was considerable variation in the survival of control larvae. In the spring months an average of $48.5 \%$ of control larvae per month survived. In summer the average survival per month increased to $73.6 \%$.

\section{DISCUSSION}

The objective in developing the EFB larval assay was to establish a feeding regime which provides a high rate of infected larvae and also 
induced clinical symptoms typical of EFB. In initial experiments to transmit EFB to larvae it was necessary to feed a high dose of M. plutonius over the whole period of the experiment to achieve high infection rates and high mortality in larvae. Even then, most larvae died only towards the end of the larval rearing period. Often the dead larvae did not exhibit the typical clinical symptoms for EFB. The colour changed to a greyish brown rather than a yellowish colour and the gut content of infected larvae was watery rather than pasty.

There was a clear relationship between the percentage of larvae dying from EFB and the infective dose of M.plutonius (Fig. 1). There was also a trend which linked an increased dose of $M$. plutonius with an increased infection rate which was not as obvious as the mortality trend. The group fed $10^{6}$ organisms/larvae had less infected individuals than the group infected with $10^{5}$ organisms (Fig. 1). However, this anomaly was not seen when both $M$. plutonius and $P$. alvei were used to infect larvae indicating the importance of both organisms in the development of EFB.

The combination of both $M$. plutonius and $P$. alvei also produced symptoms typical of that seen in field cases of EFB. It was considered important to select an inoculum feeding regime which would cause EFB in most treated larvae if the larval assay was to be useful in testing OTC and fatty acids. Using a feeding regime which used very high concentrations of $M$. plutonius was considered unsuitable; as such a regime would not reflect infection under natural condition and hence not give a realistic appraisal as to the effects of OTC and the fatty acids on EFB treatment.

A feeding regime of $500000 \mathrm{M}$. plutonius organisms in $10 \mu \mathrm{L}$ of BLD that was placed in the microtitre plate well prior to grafting of the larva, and then feeding 60000 P. alvei spores in $10 \mu \mathrm{L}$ of BLD after 67 hours was chosen. This feeding regime was the mid-point between $1 \times 10^{7}$ and $1 \times 10^{8} \mathrm{M}$. plutonius organisms $/ \mathrm{mL}$ (Fig. 2) i.e. $5 \times 10^{7} \mathrm{~mL}$ which equals 500000 organisms in $10 \mu \mathrm{L}$.

An added advantage of rearing larvae in individual wells was that they were less likely to be injured compared to previously reported methods where multiple larvae were grafted in larger cell culture dishes and later transferred into single wells (McKee et al., 2004). The rearing of individual larvae in 96-well plates also reduced the BLD required in the assay compared with the larger cell volume dishes used by McKee et al. (2004) and allowed for an accurate determination of infectious doses as larvae consumed all of the BLD containing M. plutonius or P. alvei.

Another important factor in raising larvae was the quality of the royal jelly used for preparing the BLD. In developing the larval assay there was considerable variation in the viability of the larvae associated with different batches of royal jelly used to prepare BLD. We selected batches of royal jelly that supported high larval viability.

There was considerable variation in the survival of the non-infected control larvae in this study. This varied from about $88 \%$ to $34 \%$. The survival of negative control larvae was highest in summer (DecemberFebruary) where the average control larvae survival per month was $73.6 \%$. The survival of negative control larvae in spring (SeptemberNovember) was, on average, $48.5 \%$ per month. This may have been a function of the reduced availability of nectar and pollen in spring compared with summer. However, despite these differences the data clearly demonstrated that fatty acids could not protect larvae from EFB despite the conditions under which larvae were taken from hives for the EFB larval assay.

In this study the mortality and infection rate of larvae was similar in larvae fed with M. plutonius prepared directly from infected bee larvae smears, from primary cultures and from subcultures derived from the original smear.

OTC has been the antibiotic of choice for the treatment of EFB for more than 50 years. There have only been two studies carried out to determine the sensitivity of $M$. plutonius. Hornitzky and Smith (1999) reported that there were no OTC resistant strains of M. plutonius in Australia and that all 104 isolates tested were sensitive to between 1 and $2 \mu \mathrm{g} / \mathrm{mL}$ of OTC. Waite et al. (2003) tested 80 isolates from the UK and demonstrated that all isolates were sensitive to an average concentration of $3.9 \mu \mathrm{g} / \mathrm{mL}$. Studies have also been carried out to determine what 
concentration of OTC is reached in larvae following treatment with OTC. Hornitzky et al. (1988) demonstrated that significant levels of OTC reached the larvae when fed a range of treatments. The period of detectable OTC ( $\geq 5 \mu \mathrm{g} / \mathrm{g}$ ) ranged from 1 to 9 days. The longest periods were achieved with a treatment of $1 \mathrm{~g}$ of OTC in $100 \mathrm{~g}$ of castor sugar which usually lasted five days or more. This is a recommended treatment for EFB in Australia. The peak OTC larval concentration in colonies following treatment varied from 10 to $184 \mu \mathrm{g} / \mathrm{g}$ of larval material. However, the larval OTC concentrations diminished until no OTC activity could be detected.

In this study as little as $1 \mu \mathrm{g} / \mathrm{mL}$ reduced the mortality of larvae from 93.75 (positive control) to $69.53 \%$. However, protection of such a small percentage $(24.22 \%)$ of larvae is unlikely to eliminate clinical signs of disease in a colony. A concentration of $20 \mu \mathrm{g} / \mathrm{mL}$ provided a level of protection equivalent to the negative control (Tab. IV). However, a concentration this high is unlikely to be necessary to effectively treat EFB in a honey bee colony. Lower concentrations coupled with the natural hygienic behaviour of bees would be likely to eliminate clinical evidence of disease in colonies with EFB. Hence, concentration of $2.5-10 \mu \mathrm{g} / \mathrm{mL}$ may be sufficient to provide an effective treatment for EFB in honey bee colonies.

None of the fatty acids provided any protection to larvae. This was clearly indicated by the fact that the number of dead larvae following treatment with the fatty acids was very similar to the number of deaths in the untreated positive controls. The fact that even high doses of $200 \mu \mathrm{g} / \mathrm{mL}$ of fatty acids were unable to protect any larvae whereas very small concentrations of OTC ( 1 and $2.5 \mu \mathrm{g} / \mathrm{mL}$ ) protected larvae reinforces the unsuitability of fatty acids as a treatment option.

This study clearly shows the importance of testing treatments by using both laboratory cultures of $M$. plutonius (in vitro methodology) and the EFB larval assay (in vivo methodology). The most likely reason for the discrepancy between the activity of fatty acids against M. plutonius cultures and the complete lack of protection of larvae infected with $M$. plutonius and $P$. alvei is that the fatty acids were in some way inactivated by the BLD or the gut environment of the larvae.

\section{ACKNOWLEDGEMENTS}

We thank the Rural Industries Research \& Development Corporation, Australia for funding.

Les larves d'abeilles élevées artificiellement peuvent-elles être protégées de la loque européenne par les acides gras et l'oxytetracycline?

Apis mellifera / Melissococcus plutonius / traitement contre la loque européenne / oxytétracycline / Paenibacillus alvei / acides gras

Zusammenfassung - Können Fettsäuren und Oxytetrazykline künstlich aufgezogene Larven vor einem Befall mit Europäischer Faulbrut schützen? Die Europäische Faulbrut (EFB) ist im Vergleich zur Amerikanischen Faulbrut (AFB) eine relativ schlecht untersuchte Bakterienerkrankung. Anders als bei AFB, bei der lediglich ein Erreger in den Krankheitsprozess involviert ist, sind bei EFB eine ganze Reihe von sekundären Eindringlingen bekannt, von denen Paenibacillus alvei einer der häufigsten ist (Bailey, 1960). Da die Übertragung von EFB durch unkontrollierbare äußere Bedingungen sowie durch das Ausräumen von infizierten Larven durch Adultbienen behindert wird (Bailey, 1960), ist es schwierig, eine EFB-Erkrankung in Honigbienenvölker verlässlich durch künstliche Infektion zu erzeugen. Um die Bedeutung von Melissococcus plutonius und Paenibacillus alvei für die Entwicklung von EFB zu untersuchen und um die unterschiedlichen Behandlungsmethoden ohne Störung durch Adultbienen beurteilen zu können, entwickelten wir einen quantitativen Biotest für die Übertragung von EFB auf künstlich aufgezogene Larven.

Dieser Larventest beinhaltete die Übertragung individueller Larven (jünger als $24 \mathrm{~h}$ ) in eine Vertiefung einer Mikrotiter-Platte. Jede Larve wurde mit einer Basisdiät gefüttert, die 500000 M. plutoniusOrganismen enthielt. Nach 3 Tagen wurden die Larven zusätzlich mit 60000 Sporen von $P$. alvei gefüttert, um den Verlauf von EFB besser zu simulieren. $P$. alvei ist ein verbreiteter sekundärer Eindringling im Zusammenhang mit EFB und eine Beimpfung mit $M$. plutonius allein ruft nicht die typischen klinischen Symptome einer EFB hervor.

Oxytetrazyklin (OTC) ist derzeit das Antibiotikum der Wahl bei der Bekämpfung von EFB. Obwohl OTC seit Jahrzehnten zur Bekämpfung von EFB benutzt wird, ist nach wie vor unbekannt, welche 
Konzentration von OTC in einer Bienenlarve benötigt wird, um sie vor dem Ausbruch von EFB zu schützen. Um die Wirksamkeit von OTC zu bestimmen, wurden EFB-infizierte Larven mit 0, 1, 2,5, 5, 10 oder $20 \mu \mathrm{g} / \mathrm{mL}$ OTC gefüttert. Eine Behandlung mit lediglich $1 \mu \mathrm{g} / \mathrm{mL}$ reduzierte die Mortalität der Larven von 93,75 (Positivkontrolle) auf $69,53 \%$. Eine Konzentration von $20 \mu \mathrm{g} / \mathrm{mL}$ bot bereits einen Schutz, der vergleichbar mit der negativen Kontrolle war. Allerdings ist es unwahrscheinlich, dass eine solch hohe Konzentration benötigt wird, um EFB effektiv im Bienenvolk zu bekämpfen. Geringere Konzentrationen in Verbindung mit dem natürlichen Hygieneverhalten der Bienen würden vermutlich ausreichen, um klinische Symptome in Völkern mit EFB auszuschließen. Daher sollten Konzentrationen zwischen 2,5-10 $\mu \mathrm{g} / \mathrm{mL}$, für eine effektive Behandlung von EFB im Bienenvolk ausreichen.

Falls Rückstandsprobleme vermieden werden müssen, sind alternative Methoden zur EFB-Kontrolle notwendig. Acht Fettsäuren (Undecan-, Laurin-, Myristin-, Myristolein-, Rizinol-, Ricinalaidin-, Linolen- und 13,16,19-Docosatrienoic-Säure), für die bereits eine Hemmung des Wachstums von $M$. plutonius- und P. larvae-Kulturen nachgewiesen wurden (Hornitzky, 2003), wurden im Larventest beurteilt. Keine der Fettsäuren bot einen Schutz der Larven gegenüber EFB. So war die Anzahl an toten Larven nach der Behandlung mit den Fettsäuren ähnlich hoch wie bei der unbehandelten Kontrolle. Die Tatsache, dass selbst hohe Dosen von $200 \mu \mathrm{g} / \mathrm{mL}$ an Fettsäuren keinen Schutz der Larven boten, während sehr kleine Konzentrationen von OTC ( 1 and 2,5 $\mu \mathrm{g} / \mathrm{mL}$ ) bereits die Larven schützte, untermauert die Unzweckmäßigkeit von Fettsäuren für die Bekämpfung.

Diese Untersuchung zeigt klar, dass für den Test von Behandlungen sowohl in-vitro-Methoden (Laborkultur von $M$. plutonius) als auch in-vivoMethoden (EFB-Larventest) verwendet werden sollten.

\section{Melissococcus plutonius / Europäische Faulbrut / Bekämpfung / Oxytetrazyklin / Paenibacillus al- vei / Fettsäuren}

\section{REFERENCES}

Bailey L. (1960) The epizootiology of European foulbrood of the larval honey bee, Apis mellifera Linnaeus, J. Insect Pathol. 1, 80-85.

Bailey L. (1963) The habitat of 'Bacterium eurydice', J. Gen. Microbiol. 31, 147-150.

Bailey L., Lochner N. (1968) Experiments on the etiology of European foulbrood of honey bees (Apis spp), J. Appl. Bacteriol. 55, 65-69.
Feldlaufer M.F., Knox D.A., Lusby W.R., Shimanuki H. (1993) Antimicrobial activity of fatty acids against Bacillus larvae, the causative agent of American foulbrood disease, Apidologie 24, 9599.

Hornitzky M. (2003) Fatty acids - an alternative control strategy for honeybee diseases, RIRDC Publication DAN-193A www.rirdc.infoservices. com.au/items/03-028.

Hornitzky M.A.Z., Smith L. (1998) Procedures for the culture of Melissococcus pluton from diseased brood and bulk honey samples, J. Apicult. Res. 37, 293-294.

Hornitzky M.A.Z., Smith L. (1999) The sensitivity of Australian Melissococcus pluton isolates to oxytetracycline hydrochloride, Aust. J. Exp. Agr. 39, 881-883.

Hornitzky M.A.Z., Wilson S.C. (1989) A system for the diagnosis of the major bacterial brood diseases of honey bees, J. Apicult. Res. 28, 191-195.

Hornitzky M.A.Z., Karlovskis S., Hallstrom A.L. (1988) Oxytetracycline activity in honey bee larvae following hive treatment with various oxytetracycline preparations, J. Apicult. Res. 27, 239244.

Kabara J.J. (1978) Fatty acids and derivates as microbial agents - a review, in: Kabara J.J. (Ed.), The Pharmacalogical Effects of Lipids Am Oil Chem Soc. Champaign, IL.

Kalbfleisch J.D., Prentice R.L. (1980) The Statistical analysis of failure time data, John Wiley and Sons, New York.

McKee B.A., Goodman R.D., Hornitzky M.A. (2004) The transmission of European foulbrood (Melissococcus plutonius) to artificially reared honey bee larvae (Apis mellifera), J. Apicult. Res. 43, 93-100.

Payne R.W., Murray D.A., Harding S.A., Baird D.B., Soutar D.M. (2008) Genstat for Windows (11th ed.) Introduction, VSN International, Hemel Hempstead.

Peng Y.S.C., Mussen E., Fong A., Montague M.A., Tyler T. (1992) Effects of Chlortetracycline of Honey-Bee Worker Larvae Reared In vitro, J. Invertebr. Pathol. 60, 127-133.

Shimanuki H., Knox, D.A., Feldlaufer M.F. (1992) Honey bee disease interactions: The impact of chalkbrood on other honey bee brood diseases, Am. Bee J. 132, 735-736.

Tarr H.L.A. (1936) Studies on European foulbrood of bees II. The production of the disease experimentally, Ann. Appl. Biol. 23, 558-584.

Waite R., Jackson S., Thompson H.M. (2003) Preliminary investigations into possible resistance to oxytetracycline in Mellisococcus plutonius, a pathogen of honey bees, Lett. Appl. Microbiol. 36, 20-24. 